«Філософія та політологія в контексті сучасної культури», 2020, Т. 12, Вип. 1(25)

ФІЛОСОФІЯ ТА ПОЛІТОЛОГІЯ В КОНТЕКСТІ СУЧАСНОЇ КУЛЬТУРИ

ISSN 2663-0265 (print) ISSN 2663-0273 (online)

2020. Vol. 12. Issue 1.

Journal home page: https://fip.dp.ua/index.php/FIP

\section{Василь Іванович Зінкевич}

Кандидат сільськогосподарських наук, доцент кафедри економіки та менеджменту, Дрогобицький державний педагогічний університет імені Івана Франка, вул. Івана Франка 24, Дрогобич, 82100 , Україна

E-mail: Zinkevych1971@gmail.com,_ORCID ID: https://orcid.org/0000-0003-1004-1685
Vasyl I. Zinkevych

$\mathrm{PhD}$, Associate Professor,

Economic and Management Department, Drogobych Ivan Franko State

Pedagogical University

st. I. Franko, 24, Drogobych, 82100,

Ukraine

УДК: 130.1:[316.324.7:37]

\title{
ГЕНЕЗИС ЯВИЩА ОСВІТИ В ДИСКУРСІ ЖИТТЕВОГО ЦИКЛУ ІНДУСТРІАЛЬНОЇ ЦИВІЛІЗАЦІї
}

Received 31 March 2020; revised 20 April 2020; accepted 11 May 2020

\section{DOI: $10.15421 / 352006$}

\section{Анотація}

В статті аналізується генезис системи індустріальної освіти; фундаментальна наука розглядається як підстава даного явища, а умови переходу від аграрної до індустріальної освіти постулюються як формоутворення освіти; ідеал нової людини - як логічний продукт функціонування індустріальної освіти; фундаментальна наука як підстава є невичерпною, оскільки вона живиться смислогенезом Всесвіту. Головним чинником формоутворення освіти був так званий «дух епохи» тогочасної Свропи, як простору у якому зародився і прогресував індустріалізм. Філософія як атрактор нового світового порядку відігравала помітну роль, зважаючи на ї̈ місце і роль у просторі духовного виробництва. Наукова картина світу в оцінці умов того часу відіграє одну з ключових ролей, оскільки - ие система найбільш загальних уявлень про природу, принщипів дослідження $і$ вихідних даних, щзо виробляються природознавством і соціально - гуманітарним комплексом наук на тому чи іншому етапі його розвитку. Світогляд Нового часу як чинник породження індустріальної доби відігравав важливу роль, оскільки изе не просто узагальнене уявлення про світ, а історично конкретна форма суспільної самосвідомості людини, вузловими категоріями якої слугують поняття «світ» $i$ «юдина». Світогляд за самою своєю сутністю є універсальним, оскільки інтегрує знання $і$ переконання, а також практичним. У изьому полягає функціональне призначення світогляду. Іоеологія Нового часу та ї̈ вплив на породження першоелементів системи індустріальної освіти забезпечувався релігійними настановами, волею монарха (державою) $і$ здоровим глуздом людини, головним чином батьків. Педагогічна думка на етапі зародження системи індустріальної освіти була суперечливою, оскільки в європейському просторі відбувалось гостре протистояння усталених ідей католицької релігійної освіти, з одного боку, а з іншого - інноващійних ідей Реформації і Відродження. Зміст освіти на етапі зародження індустріальної доби був достатньо суперечливим, оскільки був звалений у єдиний педагогічний котел теологічного, гуманітарного і природознавчого знання. На практиці вихід був знайдений організаційним иляхом культивування релігійних і світських навчальних закладів. Ідея «нової людини» поступово вимальовувалась на полотні освітянської діяльності завдяки ідеям авторитетних філософів, науковців і діячів мистецтвв. До того ж, Нова доба вимагала вже не просто людину гуманіста, а поставила питання про формування людини - ремісника.

Ключові слова: індустріальна освіта, жсттевий цикл, зародження, підстава, умови, нова людина, дух епохи, філософія, наукова картина світу, світогляд, ідеологія, знання.

The genesis of the education phenomenon in the life cycle discourse of industrial civilization Abstract

The genesis of the industrial education system is analyzed in the article; fundamental science is regarded as the basis of this phenomenon, and the conditions of transition from agrarian to industrial education are postulated as a form of education; the ideal of the new person - as a logical product of the functioning of industrial education; fundamental science as a basis is inexhaustible, because it feeds on the senseogenesis 
of Universe. The main factor in the formation of education was the so-called "spirit of the era" of Europe at that time, as the space in which industrialism originated and progressed. Philosophy as an attractor of the new world order has played a prominent role, considering its place and role in the space of spiritual production. The scientific picture of the world plays one of the key roles in the assessment of the conditions of that time, because it is the system of the most general ideas about nature, principles of research and initial efforts produced by the natural sciences and social and humanitarian complex of sciences at one or another stage of its development. The world view of New time as an origin factor of the industrial age played an important role, because it is not just a generalized view of the world, but a historically specific form of social consciousness of man, which nodal categories are the concepts of "world" and "man". The worldview is inherently universal because it integrates knowledge and belief as well as it is practical. This is the functional purpose of the worldview. The ideology of New time and its impact on the origin of the first elements of the industrial education system were provided by religious instruction, the will of the monarch (state) and common sense, mainly parents. Pedagogical thought at the stage of the emergence of the industrial education system was controversial, because in the European space there was a sharp opposition of the established ideas of Catholic religious education, on the one hand, and on the other-innovative ideas of the Reformation and the Renaissance. The content of education at the stage of the origin of the industrial era was quite controversial, since it was dumped into a single pedagogical cauldron, theological, humanitarian and natural sciences. In practice, the solution was found organizationally by cultivating religious and secular educational institutions. The idea of a "new man" was gradually imaged on the canvas of educational activity, thanks to the ideas of reputable philosophers, scientists and figures of art. In addition, the New Age demanded not just a humanist, but raised the question of forming an artisan man.

Key words: industrial education, life cycle, origin, basis, conditions, new man, spirit of the era, philosophy, scientific picture of the world, worldview, ideology, knowledge.

\section{Генезис явления образования в дискурсе жизненного цикла индустриальной цивилизации Аннотация}

В статье анализируется генезис системы индустриального образования; фундаментальная наука рассматривается как основание данного явления, а условия перехода от аграрного к индустриальному образованию постулируются как формообразование образования; идеал нового человека - как логический продукт функционирования индустриального образования; фундаментальная наука как основание неисчерпаема, поскольку она питается смыслогенезом Вселенной. Главным фактором формообразования образования был так называемыий «дух эпохи» тогдашней Европы, как пространства в котором зародился и прогрессировал индустриализм. Философия как аттрактор нового мирового порядка играла заметную роль, несмотря на ее место и роль в пространстве духовного производства. Научная картина мира в оченке условий того времени играет одну из ключевых ролей, поскольку это система наиболее общих представлений о природе, принципов исследования и выходных данных, производимых естествознанием и социально - гуманитарным комплексом наук на том или ином этапе его развития. Мировоззрение Нового времени как фактор порождения индустриальной эпохи сыграл важную роль, поскольку это не просто обобщенное представление о мире, а исторически конкретна форма общественного самосознания человека, узловыми категориями которой служат понятия «мир» u «человек». Мировоззрение по самой своей сутиявляется универсальным, посколькуинтегрирует знания и убеждения, а также практичным. В этом заключается функииональное назначение мировоззрения. Идеология Нового времени и ее влияние на порождение первоэлементов системы индустриального образования обеспечивался религиозными установками, волей монарха (государством) и здравым смыслом человека, главным образом родителей. Педагогическая мысль на этапе зарождения системы индустриального образования была противоречивой, поскольку в европейском пространстве происходило острое противостояние устоявшихся идей католического религиозного образования, $c$ одной стороны, а с другой-инновационных идей Реформации и Возрождения. Содержание образования на этапе зарождения индустриальной эпохи было достаточно противоречивым, поскольку были свалены в единый педагогический котел теологические, гуманитарные и естественные научные знания. На практике выход был найден организационным путем культивирования религиозных и светских учебных заведений. Идея «нового человека» постепенно вырисовывалась на холсте образовательной деятельности благодаря идеям авторитетных философов, ученых и деятелей искусства. К тому же Новое время требовало уже не просто человека - гуманиста, а поставила вопрос о формировании человека - ремесленника.

Ключевые слова: индустриальное образование, жсизненный цикл, зарождение, основание, условия, новый человек, дух эпохи, философия, научная картина мира, мировоззрение, идеология, знания. 


\section{Постановка проблеми.}

Сьогодні планетарна спільнота у повній мірі усвідомлює, що ми живемо у міжцивілізаційному просторі, що утворився у ході занепаду індустріальної і породженні інформаційної цивілізації. Це беззаперечний факт, відкидати який не можливо. Як і той, що освіта $\epsilon$ стрижень цивілізаційного розвитку, що виносить планетарну систему на вищий рівень еволюційного розвитку. У зв'язку з цим стає зрозумілим наскільки важливо теоретично опанувати алгоритмом даного процесу.

3 цієї причини вивчення життєвого циклу системи освіти індустріальної освіти є актуальною проблемою, якою мають займатися дослідники у галузі філософії освіти, теорії освіти, нарешті, історії і теорії педагогіки.

Для визначення вихідних параметрів даного дослідження системи освіти індустріальної доби слід вказати у яких саме часових вимірах вона перебувала на етапі зародження. Наша точка зору на процес зародження даного явища обгрунтована у окремому дослідженні. Початок перших революційних змін у середньовічному суспільстві та його духовних підсистемах ми пов'язуємо з виходом у 1543 році фундаментальної праці М. Коперника «Про обертання небесних сфер», у якій обгрунтовано геліоцентричну систему світу, що перевернула уяву вчених про нерухомість Землі у Всесвіті [1, с.653]. Наукова революція, викликана його відкриттям, відкинула теорії античних астрономів про положення небесних світил і дала поштовх для наукової рефлексії щодо природи їх походження.

\section{Методологія дослідження.}

Звісно, що така масштабна соціальна проблема вимагає нетрадиційного або за звичай поширеного у повсякденній науково-пошуковій практиці інструментарію дослідження. Ми вважаємо що це буде два засоби: перший - це цивілізаційний підхід, а другий - парадигма життєвого циклу соціальних систем, що нині поширена у маркетингових дослідженнях підприємств і товарів на ринку.

Мета даної статті полягає у відтворенні змісту підстави і умов генезису освіти індустріальної доби. Нагадаймо, що термін «гене-

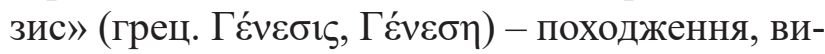

никнення, народження, зародження у даному випадку явища освіти Нової доби. Індустріальна освіта - це навчально-виховний процес підготовки людини до суспільного життя і виробничої праці у системі машинного виробництва.

\section{Виклад основного матеріалу.}

Підставою породження якісно нової освіти, на відміну від доби аграрної цивілізації, є здобутки фундаментальної науки. У такій якості фундаментальна наука, як і належить підставі, невичерпна, оскільки вона живиться смислогенезом Всесвіту [2, с.295]. При цьому під наукою ми розуміємо соціальний інститут, головною метою якого є вироблення, класифікація, переробка і використання достовірного, раціонально обгрунтованого і системно організованого знання про природу, людину i суспільство, що надходить у систему освіти і зберігається в горизонті культури.

Звісно, що визначити такий значний і багатосторонній вплив науки на породження індустріальної освіти можна було б значно точніше, якби було більш вивченим як епістемологічне і соціокультурне явище медіатор їх взаємодії тобто знання (емпіричне, донаукове, наукове, позанаукове). Але, на жаль, «в існуючій філософській літературі проблема взаємодії науки і освіти розроблена недостатньо. Icнуючі дослідження лише з різних сторін розглядають це питання. Проблематика, не має стійких тенденцій комплексного вивчення ні у сфері філософії науки, ні в галузі філософії освіти», - слушно констатує М.К. Трифонова [3, c.63].

Тригерним механізмом до оновлення системи освіти аграрної доби був вихід на перший план якісно нового поділу суспільної праці індустріальної за змістом на основі якого з'явилась професійна освітянська діяльність. Тут присутня певна діалектична гра семантичних одиниць поділу суспільної праці і суспільного поділу праці, що обумовлюють одне одного і відтворюють одне одного як причина і наслідок, що у взаємодії міняються місцями. Ці залежності є малодослідженими і тому потребують додаткової уваги з боку дослідників. Маємо надію, що вихід сьогодні на перший план духовного виробництва поста- 
вить питання перед сучасними дослідниками про більш детальне вивчення існуючих між ними залежностей. I тоді картина породження системи індустріальної освіти буде більш рельєфно відтворена.

Цей рух підстави був швидким і настільки руйнівним, що за достатньо короткий термін від гувернантської і церковно-релігійної форм освіти майже нічого, у всякому разі у Європі, не залишилось.

Форму система індустріальної освіти набувала і змінювала у залежності від зовнішніх умов, що складали матрицю ментального різноманіття тогочасних суспільств. Головним чинником був так званий «дух епохи» тогочасної Свропи, як простору у якому зародився і прогресував індустріалізм. Саме у ньому 3'являються перші світоглядні паростки нової доби, що тиском зворотного зв'язку викликають революційні зміни як позитивного, так i негативного спрямування, у глибинах соціального тіла планети.

Звертаючись сучасним поглядом у далеке минуле XVI ст., у якому зароджувалась система індустріальної освіти, можна констатувати, що він був просякнутий консервативним, а згодом й реакційним теологізмом настільки, що проти нього, у буквальному сенсі, спочатку повстав рух Реформації (Німеччина), а згодом до нього приєднався потужний рух Відродження, перші поштовхи якого ініційовані інтелектуалами Італії та Франції. Разом вони, рухи Реформації і Відродження, осучаснили «дух свого часу» настільки, що дали у життя путівку ідеям незалежності особистості людини i, як наслідок, забезпечили породження нею доби індустріалізму.

Філософія як атрактор нового світопорядку, що йшов на зміну поглядам аграрної цивілізації, відігравала помітну роль, зважаючи на ㄲi місце i роль у просторі духовного виробництва. У сучасній вітчизняній літературі панує думка, що «з погляду філософії, освіта (і виховання) є трансформацією «духу епохи» у структуру свідомості, світогляду, духовного світу, культури і загального єства особистості. Трансформований засобами освіти «дух епохи» стає іiі (особистості) стрижневою підвалиною, визначає співрозмірність (або неспіврозмірність) людини 3 їі добою. Через освіту (культуру, виховання) цей дух визначає суспільно вагомі параметри особистості. Філософія ж освіти корегує, по-перше, його суспільну якість і значення; по-друге, ефективність реалізації педагогічними заходами в умовах і можливостях наявного типу культури; по-третє, відповідність загально цивілізаційним магістралям розвитку людства у загальноісторичному аспекті» [4, с.10]. За іншим визначенням, під філософією «розуміють форму людського мислення, теоретичну форму світогляду» [5]. У свою чергу, світогляд є кінцевим продуктом впливу філософії на свідомість людини.

На етапі зародження системи індустріальної доби наукова картина світу була статичною, оскільки обумовлювалась станом науки, що концентрувалась на вивченні головним чином предметів, а не процесів, до вивчення яких вона звернулась тільки за часів Г. Гегеля. За таких обставин, вона, як продукт середньовічного мислення, була суттєвим гальмом на шляху породження індустріальної цивілізації, що потребувала більш високої динаміки змін як у сприйнятті окремих процесів, так і розуміння трансформації світу в цілому.

Світогляд Нового часу як чинник породження індустріальної доби відігравав важливу роль, оскільки це «не просто узагальнене уявлення про світ, а історично конкретна форма суспільної самосвідомості людини, вузловими категоріями якої слугують поняття «світ» i «людина». Через ці поняття суб'єкт світогляду усвідомлює, як відомо, своє призначення у світі і формує життєві установки. Світогляд за самою своєю сутністю є універсальним, оскільки інтегрує знання і переконання, а також практичним. Адже орієнтує на вирішення найважливіших проблем людського існування. Виражає імперативи поведінки людини та сенс іiі життя. У цьому полягає функціональне призначення світогляду» [5].

Не дивлячись на те, що на початку процесу породження індустріальної доби панував теологічний світогляд, на європейській арені з'явився світлий промінь Відродження, що почав ретранслювати у свідомість доби ідеї гуманізму часів Античності. Це для нас 
важливо підкреслити, що теологічний світогляд цієї доби почав руйнуватися під впливом «Відродження» (Renaissance) - культурно-філософського руху кінця Середньовіччя - початку Нового часу. Новий світогляд вже грунтувався на ідеалах гуманізму та орієнтувався на спадщину античності. За ціннісними орієнтаціями він був альтруїстським. Новий світогляд був продуктом філософії Відродження, що живилась трьома основними тенденціями: 1) гуманізмом; 2) неоплатонізмом; 3 ) натурфілософією.

«Періодом розквіту гуманізму вважається проміжок від середини XIV до середини X ст., неоплатонізму - від середини XV до першої третини XVI ст., натурфілософії - залишок XVI ст. Але гуманізм не перестав бути властивим творчості мислителів пізнього Відродження з розвитком неоплатонізму, він просто прийняв іншу форму, більш філософську і теоретично обгрунтовану, зберігши всі свої основні положення. «Гуманісти» - у широкому сенсі можна назвати майже всіх мислителів Відродження, включаючи неоплатоніків та натурфілософів. Аналогічним чином неоплатонізм не був витіснений натурфілософією, але увійшов до неї в «знятому» вигляді» [6].

Тож світоглядною спрямованістю Відродження було відкриття самоцінності людської особистості, гуманістична спрямованість пізнання. Формується нова самосвідомість людини, iï активна життєва позиція, з'являється відчуття особистої сили та таланту. Ідеалом людини епохи Відродження є їі різнобічна діяльність. Виникає тип культурного, гуманістичного індивідуалізму, який орієнтується не на практичну економічну діяльність (буржуазний індивідуалізм), а на культуру [7].

Ідеологія Нового часу та ії вплив на породження першоелементів системи індустріальної освіти забезпечувався релігійними настановами, волею монарха (державою) і здоровим глуздом людини, головним чином батьків. Загалом, схоже, що явище ідеології у цей час формувалось і використовувалось, швидше за все, як сукупність смислів, які спрямовували мислення і практичну поведінку людини у зовнішньому середовищі і гуртували людей у духовні форми організації власного співжиття починаючи $з$ племені, потім народу, що мешкав у певному регіоні i, зрештою, держави.

Нагадаємо, що панівний світогляд у цей час мав головним чином міфологічні і релігійні риси і тому він складав зміст, яким керувалась верхівка церкви і держави, що повільно виходили 3 мороку середньовіччя. Тому $\epsilon$ сенс вважати, що панівною в цей час була релігійно-державна ідеологема. Тут термін «ідеологема» вживається нами як «найменша смислова одиниця ідеології, як психологічна конструкція ідеї» [8].

Церковно-державна ідеологема у цей час, утворювала ту сукупність смислів, через яку населення мало керуватись у власній повсякденній поведінці і щодо прийняття державних рішень, зокрема й щодо навчання і виховання дітей. Причому ідеологічний апарат церкви відігравав головну роль. Ідеологічні апарати церкви і держави були у стані гострого протистояння, що не могло не позначитись на процесі породження, змісту, форм і протистояння закладів освіти.

Свідченням на користь цієї тези є думка Луї Альтюссера, що подана ним у статті «Ідеологія та державні ідеологічні апарати» [9]. У цій статті Л. Альтюссера читаємо: «...в докапіталістичному історичному періоді, який ми розглядаємо в дуже загальних рисах, цілком очевидно існував панівний державний ідеологічний апарат - церква, яка зосереджувала в собі не тільки релігійні, але й освітні та велику частину інформаційних та «культурних» функцій. Те, що вся ідеологічна боротьба 3 XVI по XVIII століття, - починаючи з перших потрясінь Реформації, - зосереджувалася на боротьбі з кліриками та релігією, пояснюється не випадковістю, а якраз панівною позицією релігійного державного ідеологічного апарату» [9].

Отже, на початок XVI століття склалися такі зовнішні умови на європейському континенті, що сприяли оновленню типу цивілізаційного розвитку і появі перших паростків індустріалізму.

Педагогічна думка на етапі зародження системи індустріальної освіти була суперечливою, оскільки в європейському просторі відбувалось гостре протистояння усталених 
ідей католицької релігійної освіти, 3 одного боку, а з іншого - інноваційних ідей Реформації і Відродження.

Вище ми зазначили, що в суспільстві на цьому етапі було гостре протистояння світоглядів папської релігії і держави, релігії і рухів Реформації і Відродження. Тому педагогічна думка цього часу формувалась у цьому протистоянні. Інтелектуальні рухи Реформації і Відродження робили свою справу не тільки в громадському житті суспільства, але й у сфері освіти.

Рух Відродження у цей час вів наступ на освітні позиції Середньовіччя і тому мав успіх у провідних країнах Свропи. Гуманісти заново відкрили, як багато в культурі та освіті зробили античні народи Греції і Риму. Їх представники «прагнули здійснювати виховання людей дії, які володіють певною професією, невибагливих, гнучких, здатних до спілкування, торгівлі, які усвідомлюють себе особистостями» [10].

Прагнучи наслідувати їх, вони і називали свій час «Відродженням», тобто відновленням античної традиції.

Саме у цей час було переосмислено педагогічний досвід Спарти і Афін, а також переоцінено 3 позицій Відродження внесок Аристотеля, що справив величезний вплив на філософську і педагогічну думку Античності і Середньовіччя. Його трактати слугували навчальними посібниками протягом багатьох століть.

Цей період історики педагогіки закономірно пов'язують з іменем Яна Амоса Коменського (1592-1670), який фактично заклав основи сучасної педагогіки. Водночас, у наявній літературі з історії педагогіки немає ясності, до якого періоду віднести його творчість: до Відродження чи Просвітництва. У нас на рахунок того, до якого етапу життєвого циклу системи індустріальної освіти віднести його педагогічне вчення, немає сумнівів, оскільки його життєвий шлях цілком вписується у хронологічні межі першого етапу (середина XVI - кінець XVII ст.). Тому цілком не випадково, що освітянська тематика доби Просвітництва, що настала після доби Відродження, пронизана ідеями «Дидактики» Яна Амоса Комен- ського.

Педагогіка Я.А.Коменського виражає загальне філософське бачення світу. Його світогляд складався під впливом ідейних потоків, які значною мірою різнилися: Античності, Реформації, Відродження. Погляди Я.А. Коменського являли собою своєрідне поєднання нових і існуючих ідей, але чаша терезів незмінно схиляється в бік прогресу і гуманізму.

«Зміст освіти в школах середньовіччя, за виразом Я.А.Коменського, був справжнім лабіринтом, у якому учні блукали впродовж довгих років, не маючи надії побачити радісне сяйво життя. Сім вільних мистецтв (так називалися шкільні предмети) не могли задовольнити прогресивних потреб суспільства XVII ст. Вироблення нової системи і методів навчання наук по суті було центральною ідеєю у всій діяльності великого чеського педагога. Систему наук, яка $б$ дала загальну картину світу, учені та філософи назвали пансофією. Відомо, що Коменський багато працював над пансофією, але майже всі його праці з цієї галузі загинули. Зміст освіти, пов'язаний із науками, Я.А.Коменський виклав у таких творах: «Велика дидактика», «Пансофічна школа», «Про користь точного найменування речей», «Промова про номенклатуру речей», «Материнська школа», «Видимий світ у малюнках», «Відкриті двері до мов», «Відкриті двері до речей» та ін. «Ми бажаємо, - говорив Коменський, - щоб розумом втілено було всю сукупність кращого з усіх галузей знань». Я.А.Коменський радить: до знань треба приєднати підготовку до діяльності, щоб зі шкіл виходили юнаки діяльні, на все здатні, вправні, старанні; у процесі навчання потрібно поєднувати три елементи: речі, розум, мову; навчальний матеріал розташовувати концентрично» [11].

Я.А.Коменський вперше сформулював ідею про організаційні рівні освіти і про іiі зміст на кожному з трьох ланок навчання і виховання молоді. Саме з цього приводу Н. Волкова зазначає: «Я.А.Коменський $є$ першим педагогом, який докладно й реалістично розробив зміст освіти й виховання дітей дошкільного віку у спеціальному фундаментальному творі «Материнська школа». Цікаві поради 
в цій галузі: дати знання 3 природознавства, оптики, географії, арифметики, геометрії, музики, мови; місцем материнської школи є сім'я, а вихователем - мати; змалку слід дитину привчати до праці; перший день у школі повинен бути радісною і світлою подією в житті дитини. Другу ланку школи - школу рідної мови, він вважає найважливішою, бо вона повинна дати основи для будь-якої подальшої діяльності юнака. Школу рідної мови повинні пройти всі діти обох статей. Запровадити в школі рідну мову як мову викладання й виховання - ця порада надзвичайно актуальна. Пропонуючи третю ланку в системі освіти - латинську школу або гімназію, Коменський дає перелік предметів, вказує, що завдання цієї школи вичерпати всю енциклопедію наук, до семи «вільних мистецтв» він додає фізику, географію, історію, мораль, причому наповнює їх новим змістом. Останню, вищу ланку в єдиній системі шкіл Я.А.Коменський назвав академією - це великий навчальний заклад типу університету, який повинен готувати вчених мужів і керівників народу. До академії Я.А.Коменський радить посилати «тільки обраних людей, цвіт людства». Академія - це школа не для аристократів і багатіїв, а вищий навчальний заклад, де здобуватимуть освіту найкращі, найталановитіші юнаки» [10]. Педагогіка Коменського протистояла схоластичному вихованню. Картаючи безсистемність навчання, марнослів'я і грубість, що панували в школі, Я.А.Коменський прагнув до формування благочестя, самостійного, діяльного мислення, здатності до різноманітної праці. Я.А.Коменський відстоював гуманістичну програму освіти. Він віддав усього себе перетворенню навчального закладу з місця безглуздого зубріння, тілесних покарань в храм розумного, що приносить радість виховання і навчання. Чеський педагог бачив школу сповнену краси, любові та уваги до дітей. Ідеальна школа повинна була стати лабораторією підготовки гуманних людей, навчених ефективно діяти на терені праці. Школа бачилася Коменським як заклад безперестанних розумових зусиль учнів, змагання умів і обдарувань, подолання моральних вад. Розумно організоване навчання, вважав учений, вимагало від наставника і вихованця зу- силь на межі їх можливостей.

Ідея «нової людини» поступово вимальовувалась на полотні освітянської діяльності завдяки ідеям авторитетних філософів, науковців і діячів мистецтва. До того ж, Нова доба вимагала вже не просто людину - гуманіста, а поставила питання про формування людини-ремісника [12]. Це пояснюється тим, що фактично етап зародження індустріальної освіти був спровокований низкою причин, серед яких викристалізувалася гостра соціальна потреба у якісно новій робочій силі, придатної до вузькоспеціалізованої праці на конвеєрі. «Наслідком таких психокультурних змін став інший розподіл характерних якостей - новий соціальний характер», - справедливо зазначає Е.Тоффлер [13, с.338]. Ця вимога з боку нової доби є цілком закономірною, оскільки сьогодні, перебуваючи на етапі переходу до інформаційної цивілізації, ми знову «перебуваємо на грані такого психокультурного потрясіння». Нас тут цікавить передусім момент виступу на поверхню поділу індустріальної праці, що сформував потребу у новій якості робочої сили, оскільки, «коли людина не дотягує до життєвого рівня свого часу, вона перетворюється - більшою чи меншою мірою - на якусь, можна сказати недолюдину» [14, с.96]. Таким чином, на поверхню соціального життя різко виступила потреба у масовій професійній освіті.

Характерно, що нові умови вимагали формування принципово іншої особистості людини від властивостей якої напряму залежить напрям і темпи науково-технічного прогресу. Зміни в людині і технології багато в чому зумовлюють зміни в економіці, у соціальній стратифікації населення, у політичних і державно-правових інститутах, у духовному світі суспільства - науці, культурі, освіті.

Таким чином, спостерігається формування суперечності поглядів на людину, оскільки 3 одного боку, звернення інтелектуальної думки суспільства часів Реформації і Відродження до людини активної і високоморальної з іншими чеснотами, що вкладаються в площину гуманізму, а з іншого, виробництво вимагало від неї більш вузької спеціалізації у сфері професійної діяльності. У цілому ж, «відповідний 
рівень iï волі, професійного вміння, освіти, загальної культури, принципи іiї ставлення до світу і до свого власного життя, що знаходять відображення в сукупності ціннісних утворень, схильних до трансформації в іiї власні усвідомлені або підсвідомі установки, ведуть до періодичної зміни технологічного способу виробництва» [15, с.31].

Як висновки, що логічно випливають 3 вищевикладеного матеріалу щодо часу і змісту етапу породження індустріальної освіти, можна зазначити наступне:

- по - перше, головним чинником або підставою породження індустріальної освіти, $\epsilon$ поділ індустріальної праці, що грунтується на подальшому розвитку фундаментальної науки, що у період XVI-XVII ст. починає активно розвиватись і поступово диференціюватись у низку прикладних галузей наук, особливо у горизонті технічного спрямування;

- по - друге, зовнішніми умовами, що сприяли появі нових форм навчально-виховного процесу індустріального походження, $є$ два види чинників: 1) матеріальні, що породжуються у вигляді поділу суспільної праці, а існують у формі системи машин і приладів; 2) духовні, що відомі нам як так званий «дух епохи», філософія, наукова картина світу, світогляд і перші ідеологеми позитивного раціоналізму Нового часу;

- по-третє, саме у цей період формуються перші інноваційні педагогічні парадигми освіти (Я.А. Коменський, Дж. Локк), у яких закладаються перші принципи освіти техногенної доби на основі здобутих наукових знань про природу і місце в ній людини;

- по-четверте, виникають перші паростки масової освіти щодо культивування фахової підготовки до професійної діяльності в уні- верситетах на основі збереження загальної гуманітарної орієнтації тогочасної освіти;

- по-п'яте, закономірно постало питання про нову людину не тільки як ремісника, але як носія нового соціального характеру, що поєднує у собі, з одного боку - професійні знання у певній галузі матеріального виробництва, заснованого на застосуванні якісно нового типу машин і агрегатів, а 3 іншого - має певний рівень загальної культури для мешкання у промисловому суспільстві загалом і в конкретному виробничому колективі шахти, фабрики або заводу.

\section{Перспективи дослідження даної теми.}

У даній статті ми лише частково змогли подати етап зародження системи індустріальної освіти. Тому їі цінність полягає лише у тому, що вона правильно розставляє акценти і визначає провідні функції чинників, як тих, що сприяли породженню явища, так і тих, що складають його зміст. Це означає, що їх треба вивчати у системному ключі у різних площинах, мається на увазі: по країнам, по формам, по змісту по наслідкам, по кадрам, по виховним наслідкам, по темпам розвитку окремих країн Європи та світу. Перспективним напрямом для істориків педагогіки є відтворення даного моменту на теренах України, оскільки такі вітчизняні освітні заклади, наприклад, як Острозька академія - відкрита у 1576 році, а Києво-Могилянська - у 1659 році.

Звісно, що перспективним є розгляд цього явища на етапі його зростання, що відбувається на основі потужного прояву фундаментальної науки і подальшого визрівання суспільного поділу праці, що детермінуються актами філософського пізнання і широким розгалуженням технічного знання.

\section{Бібліографічні посилання}

1.Коперник Н.О вращении небесных сфер. Москва, 1964. 653 с. [Електронний ресурс]. Режим доступу: http://padabum.com/x.php?id=28930.

2. Вейчжень Г. Глобальна освіта: системний та інституціональний виміри: монографія. Київ, 2019. $295 \mathrm{c}$.

3. Трифонова М.К. Наука. Образование. Человек: монография. Симферополь, 2012. С.63.

4. Філософія освіти: навч. посіб. Київ, 2009. С.10. [Електронний ресурс]. Режим доступу: http:// www.enpuir.npu.edu.ua/bitstream/123456789/4052/1/Philosophy\%20of\%20Education.pdf.

5. Філософія. Вікіпедія - вільна енциклопедія. [Електронний ресурс]. Режим доступу: https:// uk.wikipedia.org/wiki/Філософія 
6. Історія філософської думки: Античність, Середньовіччя, Відродження: лекційні матеріали. Тема 2.1. [Електронний ресурс]. Режим доступу: https://arm.naiau.kiev.ua/books/filosofia-30012017/lection/ lec2.1.html.

7. Філософія як наука і світогляд: лекційні матеріали. Тема 1. [Електронний ресурс]. Режим доступу: https://www.naiau.kiev.ua/books/filosofia-30012017/lection/lec1.html.

8. Ідіологема. Вікіпедія - вільна енциклопедія. [Електронний ресурс]. Режим доступу: https:// uk.wikipedia.org/wiki/Ідеологема.

9. Альтюссер Луї. Ідеологія та державні ідеологічні апарати. Спільне, 2010, № 3: Політика освіти. [Електронний ресурс]. Режим доступу: https://commons.com.ua/uk/ ideologiya-ta-derzhavni-ideologichniaparati/.

10. Джуринский А.Н. История педагогики и образования: учеб. для бакалавров. 3-е изд., перераб. и доп. Москва, 2013. 676с. [Електронний ресурс]. Режим доступу: https://stud.com.ua/72313/pedagogika/ istoriya_pedagogiki_ta_osviti.

11. Волкова Н. Педагогіка: посіб. Київ, 2003. 576 с. [Електронний ресурс]. Режим доступу: https:// lektsii.org/3-136209.html.

12. Философский энциклопедический словарь / гл. ред. Л.Ф. Ильичев, П.Н. Федосеев, С.М. Ковалев, В.Г. Панов. Москва, 1983. 840 с.

13. Тоффлер. Третя Хвиля / 3 англ. пер. А. Євса. К.: Вид. дім «Всесвіт», 2000. с.338.

14. Ортега-і-Гассет Х. Місія університету. Ідея університету: антологія / під. ред. М.Зубрицької. Львів, 2002. С. 96.

15. Климова Г.П. Образование в контексте цивилизационного развития: монография. - Харьков: Издатель ФЛ-П Вапнярчук Н.Н., 2007. С.31.

\section{References}

1. Kopernyk N. O vrashchenyy nebesnokh sfer. Moskva, 1964. 653s. [Elektronnij resurs]. Rezhim dostupu: http://padabum.com/x.php?id=28930.

2. Veichzhen H. Hlobalna osvita: systemnyi ta instytutsionalnyi vymiry: monohrafiia. Kyiv, 2019. 295s.

3. Tryfonova M.K. Nauka. Obrazovanye. Chelovek: monohrafyia. Symferopol, 2012. S.63.

4. Filosofiia osvity: navch. posib. Kyiv, 2009. S. 10. [Elektronnij resurs]. Rezhim dostupu: http://www. enpuir.npu.edu.ua/bitstream/123456789/4052/1/Philosophy\%20of\%20Education.pdf.

5. Filosofiia. Vikipediia - vilna entsyklopediia. [Elektronnij resurs]. Rezhim dostupu: https://uk.wikipedia. org/wiki/Filosofiia

6. Istoriia filosofskoi dumky: Antychnist, Serednovichchia, Vidrodzhennia: lektsiini materialy. Tema 2.1. [Elektronnij resurs]. Rezhim dostupu: https://arm.naiau.kiev.ua/books/filosofia-30012017/lection/lec2.1.html.

7. Filosofiia yak nauka i svitohliad: lektsiini materialy. Tema 1. [Elektronnij resurs]. Rezhim dostupu: https://www.naiau.kiev.ua/books/filosofia-30012017/lection/lec1.html.

8. Idiolohema. Vikipediia - vilna entsyklopediia. [Elektronnij resurs]. Rezhim dostupu: https://uk.wikipedia. org/wiki/Ideolohema.

9. Altiusser Lui. Ideolohiia ta derzhavni ideolohichni aparaty. Spilne. 2010. № 3: Polityka osvity. [Elektronnij resurs]. Rezhim dostupu: https://commons.com.ua/uk/ ideologiya-ta-derzhavni-ideologichniaparati/.

10. Dzhurynskyi A. N. Ystoryia pedahohyky y obrazovanyia: ucheb. dlia bakalavrov. 3-e yzd., pererab. y dop. Moskva, 2013. 676s. [Elektronnij resurs]. Rezhim dostupu: https://stud.com.ua/72313/pedagogika/ istoriya_pedagogiki_ta_osviti.

11. Volkova N. Pedahohika:posib. Kyiv, 2003. 576s. [Elektronnij resurs]. Rezhim dostupu: https://lektsii. org/3-136209.html.

12. Fylosofskyi эntsyklopedycheskyi slovar/ hl. red. L.F. Ylychev, P.N. Fedoseev, S.M. Kovalev, V.H. Panov. Moskva, 1983. 840s.

13. Toffler. Tretia Khvylia / 3 anhl. per. A. Yevsa. K.: Vyd. dim «Vsesvit», 2000. S.338.

14. Orteha-i-Hasset Kh. Misiia universytetu. Ideia universytetu: antolohiia / pid. red. M. Zubrytska. Lviv, 2002. S.96.

15. Klymova H.P. Obrazovanye v kontekste tsyvylyzatsyonnoho razvytyia: monohrafyia. Kharkov: Yzdatel FL-P Vapniarchuk N.N., 2007. S.31. 